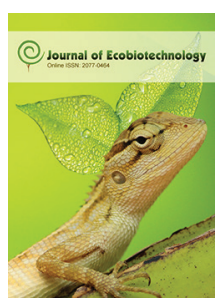

ISSN: $2077-0464$

Received: April 19, 2018 Accepted: June 09, 2018 Published: June 20, 2018

*Corresponding Author: M. A. Murtadha

Email:mosobalaje.murtadha@ uniosun.edu.ng

\section{Interaction effects of seasons and farming practices on correlation and path analysis of yield of cucumber (Cucumis Sativus L.)}

\author{
M. A. Murtadha*, T. A. Sanni \\ Department of Agronomy, College of Agriculture, Ejigbo campus, Osun State University, Osogbo, Nigeria
}

\begin{abstract}
Association among yield characters is a pre-requisite for rapid crop improvement. A study was conducted to determine the effect of seasons and stake on correlation and path effects of cucumber yield traits. The experiment comprised of 2 seasons (wet and dry), 2 practices (staked and unstaked), six cucumber varieties replicated three times in a Randomized Complete Block Design (RCBD). Planting distance was $75 \times 75 \mathrm{~cm}$. Insect pests, weeds, and fungi were controlled as recommended. Data collected were subjected to correlation and path effect analysis. In the dry season, the two practices revealed highly significant genotypic correlation $(\mathrm{P}<0.05)$ between fruit yield and vine length $\left(\mathrm{r}_{\mathrm{s}}=1.20\right.$ and 1.07$)$ and phenotypic $\left(\mathrm{r}_{\mathrm{p}}=0.69\right.$ and 0.74$)$. With days to flowering, fruit yield displayed highly significant genotypic $\left(\mathrm{r}_{\mathrm{g}}=-1.14\right.$ and -1.03) and phenotypic correlation $\left(\mathrm{r}_{\mathrm{g}}=-0.74\right.$ and -0.76). In the wet season, the two practices revealed highly significant positive genotypic $\left(\mathrm{r}_{\mathrm{r}}=0.95\right.$ and 0.84$)$ and phenotypic correlation $\left(\mathrm{r}_{\mathrm{g}}=0.84\right.$ and 0.71$)$ between fruit yield and fruit length. Path analysis showed that high yield was achieved in the dry season through the maximum effect of fruit girth 0.34 and 1.15 in the two practices and shorter days to flowering - 0.39 . In the wet season, maximum fruit yield was obtained through fruit length (5.86 and 0.28) in both practices, in addition to less fruit girth (-6.76) and short days to flowering (-0.67). In selection for high yields, the characters; vine length; fruit girth, fruit length and days to flowering can be utilized.
\end{abstract}

KEYWORDS: Cucumber, genotypic correlation, phenotypic correlation, environmental correlation, path analysis, staking

\section{INTRODUCTION}

Farmers' demand for improved varieties of cucumber (Cucumis sativus) seeds is increasing with growing acceptance of cucumber fruits in the southwest Nigeria. However, the yield of naturally climbing plant like cucumber is highly dependent on a support (stake), a practice which indirectly enhances the expression of heritable characters such as flowering, fruiting and disease prevention which can be improved through breeding [1] Staking materials can be wood, twine, string, adjacent crop or nearby fences. Direct selection for yield in some cases can mislead because yield is controlled by multiple genes and sensitive to environmental effects. The reliable means of yield improvement is therefore to select for a trait of high association with yield and quantify the level of association of such character which can be expressed as the correlation coefficient [2-3].

Study of the association among characters is the main focus of correlation analysis a technique that elaborates the degree of association among quantitative traits. This technique aids plant breeders in the selection of traits contributing to the expression of the character(s) of concern, and ultimately their improvement through hybridization. With increased demand for cucumber in this part of the country, it is necessary to intensify efforts on yield improvement and adaptation to the prevailing farming practices, environmental factors, and seasonal variation. For such efforts to be successful, determination of inter-character association among yield and its related character is a key to the rapid and outstanding achievement of this broad objective.

Although association study is quite old, but there is hardly any rule set on how much a character contributes towards the expression of other characters in a plant population. Researchers have proposed several values and dimensions of correlation among yield component traits. In their report, [4] showed that fruit yield and its components such as number of branches plant $^{-1}$, number of fruit plant ${ }^{-1}$ and percentage of pistillate nodes differed between populations and environments. Therefore, it was proposed [5] that long-fruited (length: diameter ratio) and a number of fruits could be employed for selecting the best genotypes in three cycles of phenotypic mass selection. It was also established by (5) that mean fruit number plant ${ }^{-1}$ 
and length of vine at six weeks were significantly and positively associated with yield.

Other reports also indicated an association among fruit yield of cucumber, fruit length, and girth. Significant and positive correlation between two characters usually suggests that they can be improved simultaneously and that improvement in one will influence the other [7]. In addition, it was found that fruit yield of cucumber correlated with fruit weight $(0.565)$ and a number of fruits plant ${ }^{-1}(0.457)$ [8]. It was also proposed that fruit breadth and other related characters could be used as selection indices for high cucumber yield [9]. Further, high phenotypic and genotypic correlations was observed [10] among fruit yield, fruit length, fruit diameter and other cucumber characters suggesting that selection based on these traits would ultimately improve the fruit yield in one hand, and the importance of utilizing genotypes possessing a combination of such characters in obtaining desirable high yielding segregants $[11,12]$. In instances where the magnitude of the genotypic correlation is higher than corresponding phenotypic, such cases indicate that the association is controlled mainly by gene or genes [13-15].

Path coefficient analysis thus provides more information among variables than the correlation coefficients since it reveals the association of the independent character with dependent variable as a direct effect or as consequence of indirect effect through some other traits. The objectives of present investigation were to estimate effects of early- and late-season planting and staking on the inter-relationship in yield and yield components of cucumber.

\section{MATERIALS AND METHODS}

\section{Experimental Site And Materials}

The experiment was conducted at the teaching and research farm of the College of Agriculture, Osun State University, (Latitude 7, 52’28.37”N and Longitude 4, 18’13.76”E) Ejigbo campus. The dry season production commenced in February and wet season in May 2015. The experimental area was ploughed twice and levelled. Well, cured poultry manure was applied at the rate of 28 ton ha-1. Soil samples were taken at $(0-15 \mathrm{~cm}, 15-30 \mathrm{~cm}$, and $30-45 \mathrm{~cm}$ ) depths and manure was analysed for physical and chemical properties at soil laboratory of the Osun State University, College of Agriculture, Ejigbo, Osun State of Nigeria.

\section{Experimental Design And Treatment}

The experiment was designed in a split plot whereby cultural practices were the main plot and cultivars were the subplot. The cultural practices (staked and unstaked) and the cultivars (Ashley, Market-more, Nagano F , Marketer, Poinsett, Murano 2 $\mathrm{F}_{1}$ ) were replicated three times in a Randomized Complete Block Design (RCBD). Planting was done by dibbling two seeds per hole at $75 \times 75 \mathrm{~cm}$ and later thinned to one plant stand ${ }^{-1}$ at two weeks after planting. Manual weeding was done twice in each season. Each plot size was $3.75 \mathrm{~m} \times 3.75 \mathrm{~m}$ with $1.0 \mathrm{~m}$ pathways between each block. Pests were controlled weekly using cypermethrin and mancozeb + carbendazim according to the producer's instructions Dry season planting relied fully on irrigation while wet season planting was under the rainfed system. Plants in the staked treatment were staked with bamboo woods of about $2.5 \mathrm{~m}$ long at two weeks after planting.

\section{Data Collection And Analysis}

The data collected included: vine length $(\mathrm{cm})$ (measured after the last harvest from soil surface to tip of the vine), days to flowering (determined when $50 \%$ of the plant in a row flowered), fruit length $(\mathrm{cm})$ (measured in $\mathrm{cm}$ from 10 fruits selected at random using tape rule from the apex of fruit to the base and averaged), fruit girth $(\mathrm{cm})$ (the average of the maximum breadth of the 10 fruits selected for fruit length using vernier caliper) and fruit yield (ton ha-1) (The weight in kg of total fruits in each plot were recorded using balance scale and the measurement and was converted to ton ha-1).

Genotypic and phenotypic correlation coefficients were calculated using variance and covariance components in accordance with the procedure outlined earlier [17].

The genotypic correlation coefficients were partitioned into direct and indirect effects using the path coefficient analysis proposed previously [16].

\section{RESULTS}

The results in Table 1 showed that degree of genotypic correlation coefficients were more than phenotypic correlations means it governed mainly by genetic factors and the influence of environmental factor is very low in cucumber. In the dry season, fruit yield had a highly significant positive correlation with vine length of unstaked and staked plant (1.20 and 1.07) respectively. It also displayed highly significant positive correlation (0.88) and significant positive correlation (0.87) with fruit girth of unstaked and staked plant respectively. A highly significant negative correlation was observed between fruit yield and days to flowering of unstaked (-1.14) and staked (-1.03). Association between fruit yield and fruit length was only significant in staked plant. Inter-character association showed a highly significant negative correlation between vine length and days to flowering with values -1.22 and -0.93 unstaked and staked plants respectively. However, vine length and fruit length had a highly significant association with values 1.35 and 0.82 for unstaked and staked plants respectively. Similarly, fruit yield had a highly significant positive phenotypic correlation with vine length with 0.69 and 0.74 for unstaked and staked plant respectively. A negative phenotypic correlation was also recorded between fruit yield and days to flowering of unstaked (-0.74) and -0.76) respectively. A significant phenotypic correlation was also obtained between fruit yield and fruit length of unstaked plant (0.49) and highly significant positive of staked plant (0.79).

In the wet season, fruit yield displayed highly significant positive genotypic correlation with fruit length of unstaked (0.95) and unstaked (0.84), in addition to highly significant positive correlation with fruit girth (1.10 and 0.88 ) of unstaked 
Table 1: Genotypic and Phenotypic correlation of cucumber characters in two seasons and two cultural practices

\begin{tabular}{|c|c|c|c|c|c|c|c|c|}
\hline Character & Seasons & Practice & $\begin{array}{l}\text { Correlation } \\
\text { coefficient }\end{array}$ & $\begin{array}{c}\text { Vine } \\
\text { length }(\mathrm{cm})\end{array}$ & $\begin{array}{c}\text { Days to } \\
\text { flowering }\end{array}$ & $\begin{array}{c}\text { Fruit } \\
\text { length }(\mathrm{cm})\end{array}$ & $\begin{array}{c}\text { Fruit } \\
\text { girth }(\mathrm{cm})\end{array}$ & Yield (t/ha) \\
\hline \multirow[t]{8}{*}{ Vine length } & Dry & US & $\mathrm{rg}$ & 1 & $-1.22^{* *}$ & $1.15^{* *}$ & $1.28 * *$ & $1.20 * *$ \\
\hline & & US & $r p$ & 1 & $-0.76 * *$ & 0.35 & 0.11 & $0.69 * *$ \\
\hline & & S & $\mathrm{rg}$ & 1 & $-0.93 * *$ & $0.82 * *$ & -0.01 & $1.07 * *$ \\
\hline & & S & $r p$ & 1 & $-0.66 * *$ & $0.64 * *$ & 0.45 & $0.74 * *$ \\
\hline & Wet & US & $\mathrm{rg}$ & 1 & $-0.90 * *$ & $-0.70 * *$ & $-0.74 * *$ & $-0.83 * *$ \\
\hline & & US & $r p$ & 1 & -0.16 & -0.45 & $-0.54^{*}$ & $-0.60 * *$ \\
\hline & & S & $\mathrm{rg}$ & 1 & $-0.61 * *$ & -0.35 & $0.93 * *$ & 0.22 \\
\hline & & S & $r p$ & 1 & 0.08 & -0.22 & -0.13 & 0.05 \\
\hline \multirow[t]{8}{*}{ Days to flowering } & Dry & US & $\mathrm{rg}$ & & 1 & $-0.82 * *$ & $-1.48 * *$ & $-1.14 * *$ \\
\hline & & US & $r p$ & & 1 & -0.42 & -0.10 & $-0.74 * *$ \\
\hline & & S & $\mathrm{rg}$ & & 1 & $-1.01 * *$ & $-0.52^{*}$ & $-1.03 * *$ \\
\hline & & S & $r p$ & & 1 & $-0.79 * *$ & -0.29 & $-0.76 * *$ \\
\hline & Wet & US & $\mathrm{rg}$ & & 1 & $-0.51^{*}$ & -0.16 & -0.45 \\
\hline & & US & $r p$ & & 1 & -0.17 & -0.21 & -0.06 \\
\hline & & S & $\mathrm{rg}$ & & 1 & $-0.94 * *$ & $-1.06 * *$ & $-0.83 * *$ \\
\hline & & S & $r p$ & & 1 & $-0.76^{* *}$ & $-0.80 * *$ & $-0.74 * *$ \\
\hline \multirow[t]{8}{*}{ Fruit length $(\mathrm{cm})$} & Dry & US & $\mathrm{rg}$ & & & 1 & $-0.74 * *$ & 0.37 \\
\hline & & US & $r p$ & & & 1 & 0.23 & $0.49 *$ \\
\hline & & S & $\mathrm{rg}$ & & & 1 & $0.53 *$ & $1.05^{* *}$ \\
\hline & & S & $r p$ & & & 1 & $0.64 * *$ & $0.79 * *$ \\
\hline & Wet & US & $\mathrm{rg}$ & & & 1 & $1.02 * *$ & $0.95^{* *}$ \\
\hline & & US & $r p$ & & & 1 & $0.87 * *$ & $0.84 * *$ \\
\hline & & S & $\mathrm{rg}$ & & & 1 & $0.95 * *$ & $0.80 * *$ \\
\hline & & S & $r p$ & & & 1 & $0.93 * *$ & $0.71^{* *}$ \\
\hline \multirow[t]{8}{*}{ Fruit girth $(\mathrm{cm})$} & Dry & US & $\mathrm{rg}$ & & & & 1 & $0.88 * *$ \\
\hline & & US & $r p$ & & & & 1 & $0.47^{*}$ \\
\hline & & S & $\mathrm{rg}$ & & & & 1 & $0.87 * *$ \\
\hline & & S & $r p$ & & & & 1 & $0.51 *$ \\
\hline & Wet & US & $\mathrm{rg}$ & & & & 1 & $1.10 * *$ \\
\hline & & US & $r p$ & & & & 1 & $0.71 * *$ \\
\hline & & S & $\mathrm{rg}$ & & & & 1 & $0.88^{* *}$ \\
\hline & & S & $r p$ & & & & 1 & $0.70 * *$ \\
\hline
\end{tabular}

keywords $S=$ staked and US= unstaked. ${ }^{* * *}$ : Significance at $5 \%$ and $1 \%$ leve.Is of probability respectively, $r_{g}=$ genotypic correlation coefficient and $r_{p}=$ phenotypic correlation coefficient

and staked plant respectively but negative highly correlation with days to flowering of staked plant only $(-0.83)$. Intercharacter association showed a highly significant negative genotypic correlation between vine length and days to flowering with values of -0.90 and -0.61 for unstaked and staked plant respectively. Vine length also displayed a highly significant negative correlation with fruit girth of the unstaked plant $(-0.74)$ and positive with staked plant (0.93). Interestingly, fruit length depicted highly significant genotypic correlation with fruit girth with 1.02 and 0.95 for unstaked and staked plants respectively. For phenotypic correlation, fruit yield showed highly significant positive correlation with fruit length $(0.84$ and 0.71$)$ and fruit girth $(0.71$ and 0.70$)$ for unstaked and staked plant respectively. In the same vein, fruit length had a highly significant association with fruit girth with 0.87 and 0.93 for unstaked and staked plants respectively. Environmental correlation (not displayed) was either insignificant or of less predictive value thus not presented.

The result in Table 2, showed path coefficient of cucumber characters and revealed that in the dry season, fruit girth had the largest positive direct effect on yield with 0.34 and 1.15 under unstaked and staked practices respectively. The only negative direct effect on yield -0.39 was found in days to flowering in unstaked plants. The residual effect was 0.10 and -0.52 unstaked and staked practices respectively. In wet season, fruit length had the largest positive direct effect on yield with 5.86 and 0.28 under unstaked and staked practices respectively. The largest negative effect yield of fruit girth (-6.76) and days to flowering (-0.67) was recorded under unstaked and staked respectively. The residual effect was 0.58 and 0.31 under unstaked and staked 0.31 respectively.

\section{DISCUSSIONS}

The fact that fruit girth had highly significant positive genotypic and phenotypic correlation with yield suggested that selection for broad type cucumber can result in high yield and that the genetic constituent of the trait is highly reflected by the phenotype. It thus suggests the reliability of selecting this character for yield increase in cucumber. The negative association at the genotypic level between days to flowering and 
Table 2: Path coefficient analysis of cucumber character

\begin{tabular}{|c|c|c|c|c|c|c|c|c|}
\hline Character & Seasons & Treatment & Direct effect & $\begin{array}{c}\text { Vine } \\
\text { length }(\mathrm{cm})\end{array}$ & $\begin{array}{l}\text { Days to } \\
\text { flowering }\end{array}$ & $\begin{array}{c}\text { Fruit } \\
\text { length }(\mathrm{cm})\end{array}$ & Fruit girth $(\mathrm{cm})$ & $\mathrm{rg}$ \\
\hline \multirow[t]{4}{*}{ Vine length } & Dry & US & 0.08 & & 0.48 & 0.22 & 0.43 & $1.20^{* *}$ \\
\hline & & $\mathrm{S}$ & 0.97 & & 3.81 & -3.69 & -0.01 & $1.07^{* *}$ \\
\hline & Wet & US & -2.37 & & 0.61 & -4.10 & 5.02 & $-0.83^{* *}$ \\
\hline & & $\mathrm{S}$ & 0.01 & & 0.41 & -0.10 & -0.10 & $0.22^{\text {ns }}$ \\
\hline \multirow[t]{4}{*}{ Days to flow-ering } & Dry & US & -0.39 & -0.10 & & -0.15 & -0.49 & $-1.14^{* *}$ \\
\hline & & $\mathrm{S}$ & -4.11 & -0.89 & & 4.58 & -0.60 & $-1.03^{* *}$ \\
\hline & Wet & US & -0.68 & 2.13 & & -2.97 & 1.08 & $-0.45^{\mathrm{ns}}$ \\
\hline & & $\mathrm{S}$ & -0.67 & -0.01 & & -0.26 & 0.11 & $-0.83^{* *}$ \\
\hline \multirow[t]{4}{*}{ Fruit length $(\mathrm{cm})$} & Dry & US & 0.19 & 0.10 & 0.32 & & -0.25 & $0.37^{\text {ns }}$ \\
\hline & & $\mathrm{S}$ & -4.52 & 0.79 & 4.17 & & 0.61 & $1.05^{* *}$ \\
\hline & Wet & US & 5.86 & 1.66 & 0.35 & & -6.91 & $0.95^{* *}$ \\
\hline & & $\mathrm{S}$ & 0.28 & --0.01 & 0.63 & & -0.10 & $0.80^{* *}$ \\
\hline \multirow{4}{*}{$\begin{array}{l}\text { Fruit } \\
\text { diam-eter }(\mathrm{cm})\end{array}$} & Dry & US & 0.34 & 0.11 & 0.57 & -0.14 & & $0.88^{* *}$ \\
\hline & & $\mathrm{S}$ & 1.15 & -0.01 & 2.13 & -2.41 & & $0.87^{* *}$ \\
\hline & Wet & US & -6.76 & 1.76 & 0.11 & 5.99 & & $1.10^{* *}$ \\
\hline & & $S$ & -0.11 & 0.01 & 0.71 & 0.27 & & $0.88^{* *}$ \\
\hline
\end{tabular}

$\mathrm{rg}=$ genotypic correlation coefficient, Residual: US/D $=0.10, \mathrm{US} / \mathrm{W}=0.58, \mathrm{~S} / \mathrm{D}=, \mathrm{S} / \mathrm{W}=0.31$ *, **: Significance at $5 \%$ and $1 \%$ levels of probability respectively, $\mathrm{n}=5$.

vine length indicated that selection for an early flowering plant will result in short plant type. In the dry season, the negative correlation of fruit yield with days to flowering implied that selection for cucumber variety with long days to flowering will give low fruit yield. It is possible that early flowering cucumbers escaped post pollination, biotic and abiotic stresses and maintain a high yield, this is an advantage a late flowering variety may not have. The fact that fruit girth had the highest negative direct effect on yield in all cultural practices is not surprising. Unlike other members of the Cucurbitaceae of which cucumber belongs, tender and moderate girth is the customer requirement and should be selected for in an improvement programme not broader girth. Similar negative effect of fruit girth on yield was earlier reported for by (9). Furthermore, the negative association of days to flowering with the yield of unstaked cucumber indicated that these characters are suitable for simultaneous selection to improve cucumber fruit yield for the season. In the wet season, however, fruit length and days to flowering can be considered for simultaneous selection to improve cucumber fruit yield. In summary, cucumber fresh fruit yield can directly be selected for yield improvement in both seasons and practices, in addition, high to moderate correlation coefficients and direct effects on yield displayed by characters: days to flowering and fruit length indicated their importance in simultaneous selection for high yield.

\section{ACKNOWLEDGEMENT}

The authors thanked the management of the Osun State University for providing materials and human resources for conducting this research.

\section{REFERENCES}

1. Wehner TC, Guner N. Growth stage, flowering pattern, yield and harvest date prediction of four types of cucumber tested at 10 planting dates. Proc. XXVI IHC-Advances in Vegetable Breeding. (eds.). McCreight, J.D. and Ryder, E.J., Acta Hort., 2004; 637: 223-229.
2. Murtadha S, Ariyo OJ, and Kehinde, OB. Character association of seed yield and its components in okra (Abelmoschus esculentus (L.) Moench). The Ogun J. Agric. Sci. 2004, 3: 1222 -233.

3. Machikowa T, Laosuwan P. Path coefficient analysis for yield of early maturing soybean. Songklanakarin. J. Sci. Technol. 2011; 33 4: 365-368.

4. Cramer C S, Wehner TC. Path Analysis of the Correlation between Fruit Number and Plant Traits of Cucumber Populations. Hortscience. 2000; 35 4:708-711.

5. Fan Z, Robbins MD, Staub JE. Population development by phenotypic selection with subsequent marker assisted selection for line extraction in cucumber (Cucumis sativus L.). Theor Appl Genet. 2006; 112:843-855.

6. Afangideh, U, Uyoh, EA. Genetic variability and correlation studies in some varieties of cucumber (Cucumis sativus L.) Jordan Journal of Agricultural Sciences. 2007; 3, 4: 376-384.

7. Fayeun LS, Odiyi AC, Makinde SCO, Aiyelari OP. Genetic variability and correlation studies in the fluted pumpkin (Telfairia occidentalis Hook. F.). Journal of Plant Breeding and Crop Science. 2012; 4 10: 56-160.

8. Nwofia GE, Amajuoyi AN, Mbah EU. Response of Three Cucumber Varieties (Cucumis sativus L.) to Planting Season and NPK Fertilizer Rates in Lowland Humid Tropics: Sex Expression, Yield and InterRelationships between Yield and Associated Traits. International Journal of Agriculture and Forestry. 2015; 5 1: 30-37.

9. Veena R, Sidhu AS, Pitchaimuthu M, Souravi K. Character association for fruit yield and yield traits in Cucumber (Cucumis sativus L.). Electronic Journal of Plant Breeding, 2013; 4 1: 1108-1112.

10. Hanchinamani CN, Patil MG. Correlation studies in cucumber (Cucumis sativus L.) The Asian Journal of Horticulture. 2009; 4 1: 121-125.

11. Simmonds NW. Principles of Crop Improvement. Longman Group, Singapore, 1986; Pages: 495.

12. Falconer DS, Mackay TFC. Introduction to Quantitative Genetics. $4^{\text {th }}$ Edn, Benjamin Cummings, London, UK, 1996; ISBN13: 9780582243026 , Pages: 464.

13. Abd El-Mohsen AA, Abo Hegazym SR., Taha, MH. Genotypic and phenotypic interrelationships among yield and yield components in Egyptian bread wheat genotypes. J. Plant Breed. Crop Sci. 2012; 4: 9-16.

14. Ramos LCS, Carvalho A. Shoot and root evaluations on seedlings from coffea genotypes. Brahantia, 1997; 56: 56-68.

15. Rao SA, Khan MA, Neilly TM, Khan AA. Cause and effect relations of yield and yield components in rice (Oryza sativa L.) J. Genet. Breeding, 1997; 51: 1-5

16. Dewey JR, Lu KH. Correlation and path coefficient analysis of components of crested wheat grass seed production. Agron. J. 1959; 51: 515-518.

17. Miller PA, Williams JC, Robinson HF, Comstock RE. Estimates of genotypic and environmental variances and covariances in upland cotton and their implications in selection. Agron. J. 1958; 50: 126-131. 